\title{
Development and Nutritional Analysis of Value Added Spread Instant Mix
}

\author{
Ruma Saha and Vimla Dunkwal \\ Department of Food and Nutrition, College of Home Science, RAU, Bikaner, Rajasthan, India
}

KEYWORDS Instant Food. Value Addition. Arid. Sensory Evaluation. Antinutrients

\begin{abstract}
Instant Food means simple, fast and convenient food which is easy and fast to prepare but all these preparation need value addition ultimately to improve the nutritional value. Value added spread instant mix was standardized and analyzed for their sensory, physico-chemical characteristics, nutritional and shelf life study. Value added spread instant mix was prepared by using germinated moth bean and $\beta$-carotene rich vegetables. The mean scores for sensory evaluation of developed value added spread instant mix was 8.4 against the control instant mix 7.1 on nine point hedonic ranking scale. Both the sample were subjected for physico-chemical characteristics in which developed sample secured highest scores than control sample. The developed instant mix contained 8.4 per cent moisture, $22.64 \mathrm{~g}$ protein, $2.43 \mathrm{~g}$ fat, $4.13 \mathrm{~g}$ crude fiber, $3.26 \mathrm{~g}$ ash, $59.89 \mathrm{~g}$ carbohydrate and $351.99 \mathrm{kcal}$ energy per $100 \mathrm{~g}$ on dry weight basis. In developed sample $\beta$-carotene, vitamin $\mathrm{C}$ and iron were observed $5123 \mu \mathrm{g} / 100 \mathrm{~g}, 9.07 \mathrm{mg} /$ $100 \mathrm{~g}$, and $10.75 \mathrm{mg} / 100 \mathrm{~g}$, respectively. In control sample amount of antinutrients were present in higher amount than developed sample. Fat acidity and free fatty acid also revealed satisfactory quality of the instant mixes at the end of three months storage period. Thus better quality of value added instant mixes bring considerable advantages among the arid region.
\end{abstract}

\section{INTRODUCTION}

India has been the home for ageless culinary art, having a rich heritage of a wide variety of traditional preparations. A large number of grain based traditional foods like vada, dosa, idli, khaman, pakoda, mathri etc. have been processed and their instant mixes have been developed, which are gaining popularity but all these mixes are prepared using refined cereals and pulses which are deficient in essential nutrients, which may lead to various deficiency diseases (http://www.answer.com). These problems can be reduced by value addition of processed foods such as addition of fruits, vegetables, whole cereals and pulses using germination and fermentation process. Among the pulses, moth bean (Vigna aconitifolia) the most consuming pulse for the people living in harsh environment of arid and semi- arid zones. However, it contains many antinutritional factors and these can be removed by processing of bean such as soaking and germination. The germination of pulses increases its nutritional contents. The germinated pulses have high Vitamin C content, other vitamins and folic acid. On the other hand, vegetables and fruits contain various important functional nutrients such as vitamin $C$, vitamin $E$, vitamin $K$ and $\beta$-carotene. Scanty work has been done on the health problems arising due to use of processed foods.
Therefore, investigation was planned to develop spread instant mix using $\beta$-carotene rich vegetables and germinated moth bean.

\section{METHODOLOGY}

Development of Raw Materials: The soaked moth bean were germinated in shade dried and ground for development of powder. On the other hand curry leaves, coriander leaves and sliced carrot were dried and ground for powder.

Development of Instant Mix: Most acceptable powders i.e. oven dried curry leaves, oven dried coriander leaves and oven dried balanced carrots were incorporated into germinated moth bean powder.

Organoleptic Evaluation: The developed spread instant mix was standardized using organoleptic evaluation technique with the help of semi-trained panel members using 9-point hedonic ranking scale (Swaminathan 1987).

The developed instant mix along with control sample (procured from the local market) served to the panel members in powder and product forms for organoleptic evaluation.

Physico-Chemical Properties of Instant Mix: The developed spread instant mix was evaluated for the physico-chemical properties i.e. yield (Negi 2003), water retention capacity (Mc Connell et al. 1974), Swelling index (Rasper 1980) and hygro- 
scopic water absorption capacity (Singh and Singh 1997).

Nutritional Evaluation: Dried instant mix were analyzed for moisture, crude protein, fat, fiber, Vitamin $\mathrm{C}, \beta$-carotene and iron content along with total carbohydrate and energy content (AOAC 1995).

Instant mix was also subjected for the antinutrients i.e. phytic acid (Davies and Ried 1979), oxalic acid (NIN 1980) and trypsin inhibitor (Ray and Rao 1971).

Storage Study: The storage of any product determines its wholesomeness during the definite period of time. Therefore the quality of developed instant mix was evaluated for storage of 90 days on the basis of organoleptic evaluation, fat acidity and free fatty acid.

\section{RESULTSAND DISCUSSION}

Organoleptic Evaluation: Table 1 reveals that the calculated overall mean organoleptic scores for the control instant mix was to be ranging between 7.0 to 7.2 against 8.2 to 8.7 scores for develop instant mix on nine point hedonic ranking scale (Swaminathan 1987). The statistical analysis also showed significant difference between the control and developed instant mix at one per cent level of significance.

Physico-chemical Properties: The results of physico-chemical properties of mix are depicted in Table 2. Physico-chemical properties of the sample were assessed on the basis of their yield (raw material), water retention, swelling index, water retention and hygroscopic water absorption. In developed sample it ranged from 8.06 to 98.54 per cent, $0.56 \mathrm{ml} / \mathrm{g}, 3.86 \mathrm{ml} / \mathrm{g}$ and 0.08 to 0.027 per cent, respectively. In control sample, it ranged_from $0.08 \mathrm{ml} / \mathrm{g}$. $1.60 \mathrm{ml} / \mathrm{g}$ and 0.039 to 0.163 per cent for swelling index, water retention capacity and hygroscopic water absorption capacity.

Nutritional Evaluation: Table 3 unfolds the data of nutritional contents of control and
Table 2: Water retention capacity and Swelling index $(\mathrm{ml} / / \mathrm{g})$ of instant $\mathrm{mix}$

\begin{tabular}{lcc}
\hline $\begin{array}{l}\text { Spread } \\
\text { instant mix }\end{array}$ & $\begin{array}{c}\text { Water retention } \\
\text { capacity }(\mathrm{ml} / \mathrm{g})\end{array}$ & $\begin{array}{c}\text { Swelling index } \\
(\mathrm{ml} / \mathrm{g})\end{array}$ \\
\hline Control & $0.08 \pm 0.02$ & $1.60 \pm 0.45$ \\
Developed & $0.56 \pm 0.03$ & $3.86 \pm 0.25$ \\
't' value & $4.67 *$ & $5.67 *$ \\
\hline
\end{tabular}

Values are mean \pm SD of three replicates

*significant at $1 \%$ level

***significant at $5 \%$ level

developed instant mix. Higher content of protein was found in developed ( 22.64 per cent) than its control sample(16.25 per cent) which might be due to higher protein content of moth bean i.e. $23.2 \mathrm{~g} / 100 \mathrm{~g}$ as reported by Gopalan et al. (2000) used as main ingredient in developed sample. Protein, ash, crude fiber, content in developed spread instant mix was significantly higher at 1 per cent level.

Table 4 and 5 reveals that $\beta$-carotene, vitamin $\mathrm{C}$ and iron of control sample $35 \mu \mathrm{g} / 100 \mathrm{~g}, 1.56 \mathrm{mg} /$ $100 \mathrm{~g}$ and $6.89 \mathrm{mg} / 100 \mathrm{~g}$ respectively whereas in developed sample $5123 \mu \mathrm{g} / 100 \mathrm{~g}, 9.07 \mathrm{mg} / 100 \mathrm{~g}$, and $10.75 \mathrm{mg} / 100 \mathrm{~g}$, respectively. The difference in nutrient content of the sample might be due to addition of vegetables and germination process. As Shrilakshmi (2002), reported that germination increases vitamin C at 7-22 mg/100g of pulses as well as mineral like calcium, zinc and iron are released from bound form during germination. Amount of antinutrients reduced so availability of mineral increased. In control sample antinutrient contents were significantly higher at 1 per cent level than developed sample.

Storage Study: Storage study of developed instant mix indicates its potential for being stored for a definite period of time without any deteriorating effects on its quality parameters. Instant mix was packed in 200 gauge of polythene and stored at room temperature for 3 months. Shelf life of the mix was assessed on the basis of following parameters at the interval of 15 days for 3 months of storage.

Table 1: Organoleptic acceptability of spread instant mix

\begin{tabular}{|c|c|c|c|c|c|c|c|}
\hline \multirow[t]{2}{*}{ S. No. } & \multirow[t]{2}{*}{ Product } & \multicolumn{6}{|c|}{ Mean scores of sensory characteristics on nine point scale } \\
\hline & & Colour & Appearance & Aroma & Texture & Taste & Overall acceptability \\
\hline 1 & Control & $7.1 \pm 0.73$ & $7.2 \pm 0.78$ & $7.0 \pm 0.66$ & $7.0 \pm 0.81$ & $7.2 \pm 0.91$ & $7.1 \pm 0.87$ \\
\hline 2 & Developed & $8.7 \pm 0.48$ & $8.4 \pm 0.51$ & $8.2 \pm 0.78$ & $8.7 \pm 0.48$ & $8.3 \pm 0.67$ & $8.4 \pm 0.51$ \\
\hline 3 & 't' value & $5.75^{*}$ & $4.72 *$ & $3.67 * *$ & $5.66^{*}$ & $3.05 * *$ & $4.84 *$ \\
\hline
\end{tabular}


Table 3: Proximate composition of spread instant mix (on dry weight basis)

\begin{tabular}{lcrrrrrr}
\hline $\begin{array}{l}\text { Spread } \\
\text { instant mix }\end{array}$ & $\begin{array}{c}\text { Moisture } \\
\%\end{array}$ & $\begin{array}{c}\text { Crude } \\
\text { protein }\end{array}$ & Crude fat & Crude fibre & Ash & Carbohydrate & Energy \\
\hline Control & $8.40 \pm 0.51$ & $16.25 \pm 0.16$ & $3.61 \pm 0.16$ & $2.75 \pm 0.26$ & $2.80 \pm 0.21$ & $66.19 \pm 0.01$ & $362.30 \pm 0.46$ \\
Developed & $7.65 \pm 0.02$ & $22.64 \pm 0.01$ & $2.43 \pm 0.01$ & $4.13 \pm 0.03$ & $3.26 \pm 0.67$ & $59.89 \pm 0.54$ & $351.99 \pm 0.43$ \\
't' value & $5.21 *$ & $41.50 *$ & $8.52 *$ & $18.48 *$ & $3.54 *$ & $32.17 *$ & $163.12 *$ \\
\hline
\end{tabular}

Values are mean \pm SD of three replicates

*significant at $1 \%$ level

**significant at $5 \%$ level

Table 4: Vitamin and mineral contents of spread instant mix

\begin{tabular}{lccrr}
\hline $\begin{array}{l}\text { Spread } \\
\text { instant mix }\end{array}$ & \multicolumn{2}{c}{ Vitamin } & & Mineral \\
\cline { 2 - 3 } & $\begin{array}{c}\beta \text {-carotene } \\
(\mu \mathrm{g} / 100 \mathrm{~g})\end{array}$ & $\begin{array}{c}\text { Vitamin } C \\
(\mathrm{mg} / 100 \mathrm{l})\end{array}$ & & $\begin{array}{c}\text { Iron } \\
(\mathrm{mg} / 100 \mathrm{~g})\end{array}$ \\
\hline Control & $35 \pm 0.09$ & $1.56 \pm 0.78$ & $6.89 \pm 0.11$ \\
Developed & $5123 \pm 0.66$ & $9.07 \pm 0.21$ & $10.75 \pm 0.01$ \\
't' value & $139.57 *$ & $16.77^{*}$ & $13.04 *$ \\
\hline
\end{tabular}

Sensory Evaluation: The overall mean acceptability score obtained by the sensory evaluation of the developed instant mix during 0 to 90 days of storage period ranged from 8.4 to 7.8 on nine point hedonic ranking scale (Table 6 ).

Free Fatty Acid and Fat Acidity: Table 7 depicted that free fatty and fat acidity value for developed spread instant mix ranged from 0.3 to

Table 5: Antinutrient contents of spread instant mix

\begin{tabular}{|c|c|c|c|c|c|c|}
\hline \multirow[t]{2}{*}{ Spread instant mix } & \multicolumn{6}{|c|}{ Antinutrients } \\
\hline & \multicolumn{2}{|c|}{ Phytic acid $(\mathrm{mg} / 100 \mathrm{~g})$} & \multicolumn{2}{|c|}{ Oxalic acid $(\mathrm{mg} / 100 \mathrm{~g})$} & \multicolumn{2}{|c|}{ Trypsin inhibitor $(\mathrm{mg} / \mathrm{lo0g})$} \\
\hline Control & \multicolumn{2}{|c|}{$93.54 \pm 0.41$} & \multicolumn{2}{|c|}{$4.19 \pm 0.23$} & \multicolumn{2}{|c|}{$12.06 \pm 0.55$} \\
\hline Developed & \multicolumn{2}{|c|}{$15.12 \pm 0.66$} & \multicolumn{2}{|c|}{$0.53 \pm 0.09$} & \\
\hline 't' value & \multicolumn{2}{|c|}{$128.15^{*}$} & \multicolumn{2}{|c|}{$70.23^{*}$} & \multicolumn{2}{|r|}{$\begin{array}{r}7.11 \pm 0.02 \\
58.13 * \\
\end{array}$} \\
\hline \multicolumn{7}{|c|}{$\begin{array}{l}\text { Values are mean } \pm \text { SD of three replicates } \\
* \text { significant at } 1 \% \text { level } \\
* * \text { significant at } 5 \% \text { level }\end{array}$} \\
\hline \multicolumn{7}{|c|}{ Table 6: Organoleptic acceptability of spread instant mix during storage } \\
\hline \multirow{2}{*}{$\begin{array}{l}\text { Storage period } \\
\text { (Days) }\end{array}$} & \multicolumn{6}{|c|}{ Mean scores of sensory characteristics on nine point scale } \\
\hline & Colour & Appearance & Aroma & Texture & Taste & Overall acceptability \\
\hline 0 & $8.7 \pm 0.14$ & $8.4 \pm 0.52$ & $8.2 \pm 0.13$ & $8.7 \pm 0.52$ & $8.3 \pm 0.34$ & $8.4 \pm 0.95$ \\
\hline 15 & $8.6 \pm 0.56$ & $8.3 \pm 0.13$ & $8.1 \pm 0.52$ & $8.6 \pm 0.13$ & $8.3 \pm 0.51$ & $8.3 \pm 0.72$ \\
\hline 30 & $8.6 \pm 0.23$ & $8.3 \pm 0.78$ & $8.1 \pm 0.67$ & $8.5 \pm 0.92$ & $8.2 \pm 0.13$ & $8.3 \pm 0.82$ \\
\hline 45 & $8.5 \pm 0.56$ & $8.2 \pm 0.62$ & $8.0 \pm 0.82$ & $8.4 \pm 0.82$ & $8.2 \pm 0.81$ & $8.2 \pm 0.51$ \\
\hline 60 & $8.4 \pm 0.13$ & $8.2 \pm 0.25$ & $8.0 \pm 0.51$ & $8.2 \pm 0.67$ & $8.1 \pm 0.13$ & $8.1 \pm 0.45$ \\
\hline 75 & $8.3 \pm 0.15$ & $8.1 \pm 0.73$ & $7.9 \pm 0.61$ & $8.1 \pm 0.25$ & $8.0 \pm 0.82$ & $7.9 \pm 0.63$ \\
\hline 90 & $8.2 \pm 0.17$ & $8.0 \pm 0.19$ & $7.8 \pm 0.62$ & $8.0 \pm 0.44$ & $8.0 \pm 0.13$ & $7.8 \pm 0.45$ \\
\hline F value & NS & NS & NS & NS & NS & NS \\
\hline
\end{tabular}

Values are mean \pm SD of ten panelists NS $=$ Non Significant

Table 7: Effect of storage on fat acidity (mg KOH/ $100 \mathrm{~g}$ ) and Free fatty acids ( $\mathrm{mg} / 100 \mathrm{~g}$ fat) content of stored spread instant mix (on dry weight basis)

\begin{tabular}{lcc}
\hline $\begin{array}{l}\text { Storage Period } \\
\text { (Days) }\end{array}$ & $\begin{array}{c}\text { Fat acidity } \\
(\mathrm{mg} \mathrm{KOH} / 100 \mathrm{~g})\end{array}$ & $\begin{array}{c}\text { Free fatty acids } \\
(\mathrm{mg} / 100 \mathrm{~g} \text { fat })\end{array}$ \\
\hline 0 & $0.06 \pm 0.61$ & $0.3 \pm 0.42$ \\
15 & $0.2 \pm 0.24$ & $0.7 \pm 0.04$ \\
30 & $0.5 \pm 0.13$ & $0.9 \pm 0.66$ \\
45 & $0.8 \pm 0.24$ & $1.3 \pm 0.12$ \\
60 & $1.5 \pm 0.45$ & $1.5 \pm 0.34$ \\
75 & $2.0 \pm 0.34$ & $2.0 \pm 0.13$ \\
90 & $3.2 \pm 0.43$ & $2.2 \pm 0.77$ \\
Increase in value & 3.14 & 1.9 \\
at 90 days & & \\
\hline
\end{tabular}

Values are mean \pm SD of three replicates

*significant at $1 \%$ level

**significant at $5 \%$ level
$2.2 \mathrm{mg} / 100 \mathrm{~g}$ fat as oleic acid and 0.06 to $3.20 \mathrm{mg}$ $\mathrm{KOH} / 100 \mathrm{~g}$, respectively. These values were also found under the safe limit. Thus it can be inferred from the present study that the developed spread instant mix was nutritious and safe for consumption upto 3 months of storage period. Therefore results suggest that there is a great scope of value added instant mix for entrepreneurial sector.

\section{REFERENCES}

AOAC 1995. Association of Official Analytical Chemists. Official Method of Analysis. $16^{\text {th }}$ Edition, Arlington, V.A. 
Davies NT, Reid H 1979. An evaluation of phytate, zinc, copper, iron and manganese contents and availability of soya based textured vegetable protein meat substitutes or meat extrudes. Br J Nutr, 41: 579.

Gopalan C, Rama Shastri V B, Balasubramanian SC 2000. Nutritive Value of Indian Foods. Hyderabad: National Institute of Nutrition, Indian Council of Medical Research.

McConnell AA, Eastwood MA and Mitchell WD 1974. Physical characteristics of vegetables and food stuffs that could influence bowel function. Sci Food Agric, 25: 1457.

Negi A 1999. Nutritional Evaluation of Some High Yielding Varieties of Moth Bean (Phaseolus aconitifolia): Effect of Domestic Processing and Cooking Methods. M.Sc. Thesis, Hisar, India: CCSHAU.
NIN 1980. A Manual of Laboratory Products Techniques. Hyderabad: NIN, pp. 49-53.

Rasper VF 1980. Chemical and physical properties of dietary cereal fiber. Food Technol, 33: 40-44.

Ray DN, Rao PS 1971. Evidence, isolation, purification and some properties of a trypsin inhibitor in Lathyrus sativum. Agric Food Chem, 19: 257.

Shrilakshmi B 2002. Food Science. $2^{\text {nd }}$ Edition, Delhi: New Age International Limited, Publishers, pp. 7071 .

Singh U, Singh B 1997. Functional properties of sorghum peanut composite flour. Cereal Chem, 68(5): 460463.

Swaminathan MS 1987. Food Science Chemistry and Experimental Food. Bangalore: The Bangalore Printing and Publishing Co. Ltd., (http://www.answer. com) 